\title{
PENERAPAN TEKNIK BRAINSTORMING TERHADAP KEMAMPUAN MENGAPRESIASI PUISI SISWA KELAS VI SD INPRES LAPPARA KECAMATAN TOMBOLO PAO KABUPATEN GOWA
}

\author{
Baharuddin \\ SD INPRES LAPPARA TOMBOLO PAO \\ NIP 196109251982061001 \\ baharuddin@gmail.com
}

\begin{abstract}
Abstrak
Tujuan penelitian tindakan kelas ini adalah untuk mengetahui kemampuan siswa mengapresiasi puisi melalui teknik brainstorming yang diharapkan dapat meningkatkan proses dan hasil belajar bahasa Indonesia khususnya apresiasi puisi pada siswa kelas VI SD Inpres Lappara dengan jumlah subjek sebanyak 24 orang. Teknik yang digunakan dalam penelitian ini adaah deskripsi kualitatif. Adapun rencana penelitian tindakan kelas ini dilaksanakan dalam dua siklus. Tiap siklus terdapat empat tahapan yaitu perencanaan, pelaksanaan, pengamatan, dan refleksi.

Hasil penelitian tindakan kelas ini menunjukkan bahwa: (1) terjadi perubahan positif terhadap aktivitas pada setiap siklus. (2) perolehan nilai rata-rata meningkat sesuai kriteria: (tema 65 pada siklus I meningkat menjadi 68,83 pada siklus II, rasa 65,69 meningkat menjadi 68,83, nada 66,63 meningkat menjadi 73,96, dan amanat 67,79 meningkat menjadi 72,54); (3) rata-rata persentase kemampuan mengapresiasi puisi meningkat dikaitkan dengan kriteria ketuntasan minimal yaitu nilai kecil dari 65 (52,09\% pada siklus I menurun menjadi $12,50 \%)$ dan nilai besar dari 65 (47,915\% meningkat menjadi 87,50\%) menunjukkan suatu hasil yang signifikan. Sesuai dengan hasil PTK ini dinyatakan meningkat secara signifikan. Oleh karena itu, kepada guru kelas VI SD Inpres Lappara Kecamatan Tombolo Pao Kabupaten Gowa diharapkan dapat menerapkan teknik brainstorming terhadap pembelajaran bahasa Indonesia khususnya apresiasi puisi.
\end{abstract}

Kata kunci: teknik brainstorming, kemampuan, apresiasi, puisi

\begin{abstract}
The purpose of this classroom action research is to know the ability of students to appreciate poetry through brainstorming technique which is expected to improve the process and the result of learning Indonesian especially poetry appreciation in grade 6 students of Inpres Lappara Elementary School with the number of subject as many as 24 people. The technique used in this research is a qualitative description. The class action research plan is implemented in two cycles. Each cycle has four stages: planning, implementation, observation, and reflection.

The results of this class action research indicate that: (1) there is a positive change of activity in each cycle. (2) the average score increased according to the criteria: (theme 65 in cycle I increased to 68.83 in cycle II, 65.69 increase to 68.83, 66.63 note increased to 73.96, and mandate 67, 79 increased to 72.54); (3) the average percentage of the ability to appreciate the increased poetry is related to the minimum completeness criterion that is small value of 65
\end{abstract}


(52,09\% in cycle I decrease to 12,50\%) and big value from 65 (47,915\% increase to 87,50\%) shows a significant result.

In accordance with the results of this PTK expressed significantly increased. Therefore, to grade 6 teachers of Inpres Lappara Elementary School, Tombolo Pao, Gowa District is expected to apply brainstorming technique to Indonesian language learning especially poetry appreciation.

\section{Keywords: brainstorming technique, ability, appreciation, poetry}

\section{A. PENDAHULUAN}

Coleridge pernah menegaskan bahwa suatu puisi tidak perlu samar karena bukanlah kepopuleran yang merupakan tujuan utamanya. Cukup bila karya tersebut untuk orang tertentu saja. Hal ini ada benarnya, tetapi untuk kalimat kedua pernyataan itu tentu kita tidak menerimanya. Bukankah puisi diciptakan untuk masyarakat. Kita malah sependapat dengan Robert C. Pooley yang menyatakan bahwa orang yang menutup telinga akan puisi dia akan terpencil dari suatu wilayah yang penuh harta kekayaan berupa pengertian manusia, pandangan perorangan, sensitivitas yang menonjol; upaya yang dituntut mamahami, menghayati puisi itu sama beratnya dengan yang dituntut setiap kehidupan manusia (Tarigan, 1985).

Sependapat dengan pujangga terkenal yang karya-karyanya seperti Oedipus, Antigone, Hamlet, Mchbet Mahabrata, Ramayana, Brata Yuda, ditulis dalam bentuk puisi. Namun, puisi bukan hanya milik para pujangga besar, tetapi milik semua orang. Puisi dapat dipergunakan untuk berkomunikasi verbal. Kaitannya dengan kehidupan manusia, puisi telah mempunyai andil yang besar dengan kehidupan sehari-hari. Dunia ini telah diperindah dengan kehadiran puisi termasuk dalam pembelajaran mulai pada tingkat Sekolah Dasar sampai Perguruan Tinggi.

Sejak lahirnya, puisi memang menunjukkan suatu ciri khas tertentu. Meskipun puisi telah mengalami perkembangan dan perubahan yang sangat pesat dari tahun ke tahun. Bentuk karya sastra puisi memang diciptakan oleh penyair dalam bentuk yang puitis. Dalam konsepnya, penyair mengonsentrasikan dengan kekuatan bahasa yang puitis. Penyair pengungkapkan perasaannya bukan dengan konsep prosa, tetapi terkonsep dalam pikiran yang sifatnya puitis.

Puisi dapat dibedakan dengan karya sastra yang lain, karena bahasanya ekonomis serta pengungkapannya yang intensif. Oleh karena itu, untuk mengapresiasi sebuah puisi, diperlukan adanya perhatian yang sungguh-sungguh. Puisi harus dibaca berulang-ulang sambil merenung, sebab pembacaan hanya sepintas maknanya sukar dipahami, baik makna yang tersirat maupun makna yang tersurat. Effendi (1982) menyatakan bahwa untuk mengapresiasi sastra harus memahami tiga hal yaitu teori sastra, kritik dan esai sastra, serta sejarah sastra.

Mengapresiasi puisi tidak hanya tahu baca, tetapi harus tahu tentang apa yang dibaca. Untuk sampai pada tahap ini, tentunya berbagai usaha harus dilakukan. Hal ini harus dipahami keunikan yang terkandung dalam puisi dibandingkan dengan wujud karya sastra lainnya. Jadi, untuk mengapresiasi puisi diperlukan pengetahuan tentang perpuisian, pengalaman, serta pemahaman terhadap sebuah karya sastra puisi.

Sesungguhnya puisi dapat dianggap sebagai pengungkapan perasaan, tata hidup dan kehidupan dengan segala liku-likunya. Dengan kata lain apa yang diutarakan dalam sebuah puisi dapat ditemukan dalam kehidupan sehari-hari. Oleh karena itu, 
puisi dapat dipahami maknanya melalui apresiasi dengan teknik Brainstorming mengenai tema (sense), sara (feeling), nada (tone), dan amanat (intention) yang tersirat dan tersurat dalam sebuah karya sastra puisi.

\section{B. TINJAUAN PUSTAKA}

\section{Pengertian Apresiasi Sastra}

Sering timbul pertanyaan apakah apresiasi sastra itu? Pertanyaan ini sering dengan jawaban teoretis yang biasanya menggambarkan pengertian sebagai perilaku konkret. Pertanyaan lain yang sering muncul adalah bagaimanakah pengertian aresiasi terhadap cipta sastra? Cipta sastra; sajak, cerita atau drama adalah perwujudan pengalaman sastrawan yang diungkapkan dengan jujur, terus-terang, sungguh-sungguh dan penuh imajinasi, dan bahasa yang khas pula.

Effendi (1974) mengungkapkan bahwa seseorang yang mempunyai kemampuan mengapresiasi cipta sastra biasanya peka pikiran kritisnya dan peka perasaannya terhadap cipta sastra. Artinya ia dengan mudah tersentuh, tertarik atau terpikat dengan pikiran kritis, dan perasaan yang baik. Senang membaca sajak/puisi, cerita atau drama, senang membicarakannya, senang mendengarkannya atau menyaksikan pentas drama. Hal inilah merupakan perilaku konkret yang harus diperlihatkan seseorang yang peka pikiran kritis dan perasaannya maka dapat dikatakan seseorang mempunyai kemampuan apresiasi karya sastra.

Kegiatan menggauli cipta sastra sebagai kegiatan yang dilakukan secara langsung dapat disebut apresiasi sastra. Artinya kita langsung membaca bermacam-macam puisi, cerita atau drama dari berbagai sastrawan dan zamannya atau langsung mendengar sajak yang dideklamasikan, cerita yang dibacakan, dan drama yang dipentaskan. Membaca, mendengarkan, dan menyaksikan yang dilakukan dengan sungguh-sungguh cara inilah yang disebut dengan kegiatan apresiasi karya sastra.

Dari uraian di atas, maka dapat disimpulkan bahwa apresiasi sastra adalah kegiatan yang dilakukan terhadap karya sastra dengan sungguh-sungguh terhadap suatu karya sastra sehingga timbul pengertian, penghargaan, kepekaan pikiran yang kritis dan kepekaan perasaan yang baik terhadap karya sastra.

\section{Pengertian Puisi}

Berbagai batasan puisi yang dikemukakan oleh para pakar dan sastrawan. Banyak pendapat mengenai puisi, baik yang berhubungan dengan struktur fisik maupun struktur batin. Namun, ada juga yang memberikan batasan yang meliputi kedua struktur itu. Ali (1999) puisi adalah ragam sastra yang bahasanya terikat oleh irama, ritma, rima serta penyusunan larik dan bait. Slametmuljana menyatakan bahwa puisi merupakan bentuk kesusastraan yang menggunakan pengulangan suara sebagai ciri khasnya; James Reeves memberikan batasan bahwa puisi adalah ekspresi bahasa yang kaya dan penuh daya pikat; Clice Samson memberi batasan bahwa puisi adalah bentuk pengulangan bahasa yang ritmis, yang mengunkapkan pengalaman intelektual yang bersifat imajinatif dan emosional (Waluyo, 1987).

Puisi adalah karya sastra yang bersifat imajinatif, karena bahasa sastra bersifat konotatif karena banyak menggunakan makna kias, makna lambang atau majas. Jika dibandingkan dengn bentuk karya sastra yang lain, puisi lebih bersifat konotatif, bahasanya memiliki berbagai kemungkinan makna. Atas dasar kemungkinan makna itu sehingga siswa mengalami kesulitan memahami makna yang terkandung di dalanya. Hal ini disebabkan perlu adanya pengonsentrasian atau pemadatan segenap kekuatan bahasa puisi. Struktur fisik dan struktur batin puisi 
keduanya bersenyawa secara padu (Hayati, 1990).

Puisi merupakan bentuk kesusastraan yang menggunakan pengulangan bahaa sebagai ciri khasnya. Pengulangan kata itu menghasilkan rima, ritma, dan musikalitas. Di dalam puisi terdapat bentuk berupa larik, bait, dan pertalian makna antara larik dengan bait. Karena penyair berusaha mengonkretkan pengertian dan konsep abstrak dengan menggunakan pengimajian, pengiasan, dan pelambangan dalam mengungkapkan pengalaman jiwanya. Clive Samson (dalam Tarigan, 1986) memberi batasan puisi sebagai bentuk pengucapan bahasa yang ritmis yang mengungkapkan pengalaman intelektual yang bersifat imajinatif dan emosional.

Secara etimologi kata puisi berasal dari bahasa Yunani poeiesis yang berarti penciptaan. Kemudian dipersempit menjadi "hasil seni sastra" yang kata-katanya disusun menurut syarat tertentu. Dalam bahasa Inggrs kata puisi adalah poetry yang erat hubungannya dengan kata poet yang berasal dari kata Yunani membuat, mencipta. Poet dapat juga berarti orang yang mencipta melalui imajinasi (Tarigan, 1986).

Dari batasan di atas, dijelaskan bahwa unsur bahasa yang diperindah itu dapat dijelaskan melalui kata konkret dan majas (bahasa figuratif). Secara terinci majas dan kata konkret itu menjadi pengimajian, pelambangan, dan pengiasan. Uraian yang dimaksudkan menjelaskan bahwa bahasa yang digunakan dalam puisi adalah bahasa konotatif yang multiinterpretable.

Waluyo (1987) menyatakan bahwa untuk memperjelas pengertian puisi, dapat memperhatikan pedoman sebagai berikut: (1) dalam puisi terjadi pengonsentrasian atau pemadatan unsur kekuatan bahasa; (2) dalam penyusunannya unsur bahasa itu dirapikan, diperbagus, diatur sebaikbaiknya dengan memperhatikan irama dan bunyi; (3) puisi adalah ungkapan pikiran dan perasaan penyair yang berdasarkan pengalaman jiwa yang bersifat imajinatif; (4) bahasa yang dipergunakan bersifat konotatif ditandai dengan kata konkret lewat pengimajian, pelambangan, dan pengiasan kata konkret dan bahasa figuratif, dan (5) bentuk fisik dan bentuk batin puisi merupakan kesatuan yang padu.

Puisi adalah salah satu bentuk sastra yang mengungkapkan pikiran dan perasaan penyair secara imajinatif dan disusun dengan mengonsentrasikan semua kekuatan bahasa yakni dengan mengonsentrasikan struktur fisik dan struktur batinnya. Kedua unsur itu yang saling mengikat keterjalinan dan semua unsur itu membentuk totalitas makna yang utuh. Oleh karena itu, dalam penafsiran puisi tidak terlepas dari faktor genetik puisi. Faktor genetik puisi dapat menjelaskan makna yang melatarbelakangi kebudayaan khas penyair. Unsur genetik adalah penyair dan kenyataan sejarah (Waluyo, 1987).

\section{Unsur-unsur pembangun puisi}

Waluyo (1987) memberika gambaran tentang puisi sebagai suatu struktur utuh dapat dilihat dari sebuah tembang Jawa. Sebuah tembang Jawa tidak hanya diatur oleh struktur bunyi, suku kata, dan baris namun juga diatur oleh aturan makna itu sendiri yang harus memenuhi syarat. Meskipun aturan kebahsaaan sudah memenuhi syarat aturan makna tidak dipenuhi maka tembang Jawa tersebut tidak bernilai. Berikut ini ditampilkan sebuah contoh puisi karya Toto Sudarto Bahtiar (dalam Wluyo, 1987) yaitu sebagai berikut:

\section{GADIS PEMINTA-MINTA}

Setiap kita bertemu, gadis kecil berkaleng kecil

Senyummu terlalu kekal untuk kenal duka

Tengadah padaku pada bulan merah jambu

Tapi kotaku jadi hilang, tanpa jiwa.

Ingin aku ikut, gadis kecil berkaleng kecil

Pulang kebawah jembatan yang melulur sosok 
Hidup dari kehidupan angan-angan yang gemerlapan

Gembira dari kemayaan riang.

Duniamu yang lebih tinggi dari menara katedral

Melintas-lintas di atas air kotor, tapi yang begitu kau hafal

Jiwa begitu murni, terlalu murni

Untuk dapat membagi dukaku.

Kalau kau mati, gadis kecil berkaleng kecil

Bukan di atas itu tak ada yang punya

Dan kotaku, oh kotaku

Hidupnya tak lagi punya tanda.

Dalam puisi yang ditandai dengan nada keharuan penyair itu dapat menangkap lambang, kiasan bunyi, pilihan kata, dan unsur puisi yang khas untuk nada terharu tersebut. Ungkapan atau senyummu terlalu kekal untuk kenal duka/ dan /tengadah padaku pada bulan merah jambu/ sangat tepat untuk menggambarkan suasana sedih dan terharu semacam itu. Kesedihan dan keterharuan belum tentu dapat diwakili oleh ungkapan/ bulan merah jambu/ jika kesedihan dan keterharuan bukan seperti yang dialami penyair dalam puisi di atas keasedihan dan keharuan penyair bukan disebabkan oleh keadaan dirinya sendiri yang menderita atau sanak saudaranya, namun oleh keadaaan "Gadis Kecil Berkaleng Kecil". Kesedihan dan keharuan oleh rasa solidaritas kemanusiaan. Oleh sebab itu, ungkapan-ungkapan yang dicetuskan tidak terlalu menghancurkan perasaan, namun cukup membuat diri pembacanya terharu.

Apa yang dilihat melalui bahasanya yang tampak, disebut struktur fisik puisi yang secara tradisional disebut bentuk atau bahasa, atau unsur bunyi. Sedangkan makna yang terkandung dalam puisi yang tidak secara langsung dapat dihayati, disebut struktur batin atau struktur makna. Kedua unsur tersebut kerena tediri atas unsur-unsur lebih kecil yang bersama-sama membentuk kesatuan sebagai struktur.
Struktur fisik biasa disebut juga struktur sintaktik puisi. Istilah ini memang tidak tepat, sebab kesatuan unsur-unsur kebahasaan dalam puisi tidak membentuk struktur sintaktik, tetapi membentuk barisbaris puisi. Oleh sebab itu, penulis merasa bahwa sebutan struktur fisik lebih tepat. Sedangkan struktur batin, sering disebut struktur tematik dan struktur semantik. Penanaman tersebut tepat juga. Oleh sebab itu, penulis menggunakan istilah struktur batin karena berisi ungkapan batin penulisnya.

Struktur fisik puisi adalah media untuk mengungkapkan makna yang hendak disampaikan penyair. I.A.Richards (dalam Tarigan, 1986 dan Waluyo, 1987) sorang kritikus sastra yang terkenal menyatakan kepada kita bahwa suatu puisi mengandung suatu "makna keseluruhan" yang merupakan perpaduan dari tema (sense), perasaan (feeling), nada (tone), dan amanat (intention). Keempat unsur itu menyatu dalam wujud penyampaian bahasa penyair tergolong dalam struktur batin atau disebut juga hakikat puisi. Berikut kita perhatikan uraian hakikat puisi secara singkat.

\section{a. Tema/makna (sense)}

Tema merupakan gagasan pokok (subject-matter) yang dikemukakan oleh penyair. Pokok persoalan itu dalam jiwa penyair menjadi landasan utama pengucapannya. Jika makna yang terkandung dalam suatu puisi dengan desakan yang kuat berupa hubungan penyair dengan Tuhan puisi pasti bertema ketuhanan. Jika desakan adalah rasa belas kasih atau kemanusiaan maka puisi bertema cinta atau kemanusiaan. Seperti puisi "Kembang Setengah Jalan" beriku ini.

\section{Kembang Setengah Jalan \\ Mejaku hendak dihiasi \\ Kembang jauh dari gunung.}

Kau petik sekarang kembang, 
Jauh jalan panas hari,

Bunga layu setengah jalan.

Setelah membaca puisi di atas, dapatlah ditarik kesimpulan bahwa temanya "sesuatu yang tak sampai". Sesuatu itu adalah kembang, dalam kehidupan masyarakat adalah kasih, cinta, wanita. Tegasnya tema puisi di atas adalah kasih tak sampai, bertepuk sebelah tangan. Hal ini tampak pada baris "Bunga layu setengah jalan". Jelas pula pada baris "jauh jalan dan panas hari" yang mengandung makna bahwa sekalipun bunga telah layu dipaksakan untuk menghiasi meja, toh sudah terlambat, tidak ada gunanya, sia-sia belaka (Tarigan, 1986).

Berikut puisi dengan tema Ketuhanan biasanya menunjukkan "religiuos experience" atau pengalaman religi penyair. Pengalaman religi seorang penyair dirasakan atas pengalaman hidup penyair secara konkret. Jika penyairnya bukan orang religius yang khusyuk dalam hal religi maka sulit diharapkan ia akan menghasilkan puisi yang bertema ketuhanan yang mendalam.

Uraian berikut betapa dalam rasa Ketuhanan yang ditunjukkan oleh Amir Hamzah pada sajak yang berjudul "Doa" sebagai berikut.

Dongan apakah kubandingkan
pertemuan kita,
Kekasihku?
Dengan senja samar sepoi, pada masa
purnama
Meningkat naik, setelah menghalaukan
panas
Payah terik.
Angin malam menghembus lemah,
menyejuk badan,
Melambung rasa menayang pikir,
membawa angan ke
bawah kursimu.
Hatiku terang menerima katamu,
bagai bintang
memasang lilinnya.

\author{
Kalbuku terbuka menunggu \\ kasihmu, bagai sedap \\ malam menyirak kelopak. \\ Aduh, kekasihku, isi hatiku dengan \\ katamu, \\ penuhi dadaku dengan cayamu, biar \\ bersinar \\ layu! \\ mataku sendu, biar terbinar galakku
}

Kedalaman rasa Ketuhanan itu tidak terlepas dari bentuk fisik yang terlahir dalam pemilihan kata, ungkapan, lambang, kiasan, dan sebagainya yang menunjukkan betapa erat hubungan antara penyair dengan Tuhan. Juga menunjukkan bagaimana penyair ingin agar Tuhan mengisi seluruh kalbunya. Betapa sungguh-sungguh sang penyair menyerahkan diri secara total, dapat kita rasakan secara nyata dalam sajak tersebut (Waluyo, 1987).

Demikian tema partiotisme dapat meningkatkan perasaan cinta akan bangsa dan tanah air. Banyak puisi yang melukiskan perjuangan merebut kemerdekaan dan mengisahkan riwayat pahlawan yang berjuang melawan penjajah. Tema patriot diwujudkan dalam bentuk usaha penyair untuk membina kesatuan bangsa atau membina kenasionalan. Sajak Taufiq Ismail yang berjudul "Kami adalah Pemilik Sah Republik Ini" meningkatkan kesadaran nasional pembacanya. Pembaca berusaha agar tidak penonton pembangunan. Penyair memberi nasihat bahwa kita semua adalah pemilik sah republik ini. Seperti puisi berikut. Ini

Kita adalah Pemilik Sah Republik

Tidak ada lagi pilihan lain. Kita harus

Berjuang terus

Karena berhenti atau mundur

Berarti hancur.

Apakah akan kita jual keyakinan kita

Dalam pengabdian tanpa harga

Akan maukah kita duduk dalam satu meja 

lalu

Dengan para pembunuh tahun yang

Dalam setiap kalimat yang berakhiran:

"Duli Tahanku"?

Tidak ada lagi pilihan lain. Kita haru

Berjalan terus

Kita adalah manusia bermata kayu, yang di tepi jalan

Mengacungkan tangan untuk oplet dan bus yang penuh

Kita adalah berpuluh juta yang bertahun hidup sengsara hama

Dipukul banjir, gunung api, kutuk dan

Dan bertanya-tanya diam inikah yang namanya merdeka

Kita yang tak punya kepentingan dengan seribu slogan

Dan seribu pengeras suara yang hampa suara.

Tidak ada lagi pilihan lain. Kita harus Berjalan terus.

Dari pengungkapan kisah perjuangan bersejarah itu, pembaca merasakan getaran patriotisme dan perjuangan tanpa pamrih untuk menumbangkan kekuasaan orde lama, dan selanjutnya menegakkan keadilan dan kebenaran di bumi Indonesia.

Demikian ulasan tema yang merupakan pokok pikiran penyair yang dilandasi filsafat hidup penyairnya. Oleh karena itu, dalam kaitan ini penulis hanya membicarakan yang brkaitan dengan tujuan pendidikan nasional sebagai bahan pembelajaran di sekolah, khusus pembelajaran apresiasi puisi.

\section{b. Rasa (feeling)}

Dalam puisi, susana penyair ikut diekspresikan harus dapat dihayati pembaca. Pengungkapan tema oleh penyair kadang sama, perasaan pasti berbeda-beda sehingga puisi yang diciptakannya berbeda pula. Perasaan Chairil Anwar berbeda dengan Toto Sudarto Bachtiar berbeda pula dengan Rendra dan Arifin C, Noer dalam menghadapi pengemis. Demikian perasaan Taufiq dalam puisinya Karangan Bunga. Karangan Bunga
Tiga anak kecil

Dalam langkah malu-malu

Datang ke Salemba

'Ini dari kami bertiga

Pita hitam pada karangan bunga

Sebab kami ikut berduka

Bagi kakak yang ditembak mati siang tadi!'

Perbedaan perasaan haru disebabkan oleh perbedaan keterlibatan batin antara Toto dengn Taufiq. Toto melibatkan rasa harunya terhadap gadis kecil berkaleng kecil (Gadis Peminta-minta), sedangkan Taufiq kurang melibatkan keharuannya kepada tiga anak kecil yang membawa karangan bunga (Waluyo, 1987). Namun, puisi di atas menggugah hati serta membuat air mata para penikmatnya berlinang-linang dan sekaligus merasa dirinya berada di Salemba Jakarta bersama tiga anak kecil mewakili pelajar Indonesia kala itu.

Demikian rasa yang dapat kita hayati dalam puisi. Perasaan ungkapan penyair berpengaruh terhadap pemilihan bentuk fisik puisi. Begitu suasana perasaan penyair ikut diekspresikan dan harus dihayati oleh pembacanya.

\section{c. Nada (tone)}

Nada dalam dunia perpuisian adalah sikap penyair terhadap pembacanya atau para penikmat karyanya. Dalam menulis puisi penyair mempunyai sikap terhadap pembaca, apakah dia ingin bersikap menggurui, menasihati, mengejek, menyindir atau bersikap mnceritakan sesuatu kepada pembaca. Nada dan suasana dalam puisi saling berhubungan karena nada puisi menimbulkan suasana terhadap pembacanya. Jika dalam sebuah puisi, penyair menuangkan nada duka maka dapat menimbulkan suasana ibah hati pembaca.

Dalam puisi Indonesia sering kita lihat nada-nada sinis seperti karya Taufiq Ismail, Bung Usman. Berikut kita nikmati kesinisan Taufiq Ismail pada puisi berikut. 
Dari Catatan Seorang Demonstran

Inilah peperangan

Tanpa jenderal, tanpa senapan

Pada hari-hari yang mendung

Bahkan tanpa harapan.

Di sinila keberanian diuji

Keberanian dicoba dihancurkan

Pada hari-hari berkabung

Di depan menghadang ribuan lawan.

Nada kesinisan ini muncul kebencian dan mengakibatkan pemberontakan seperti yang kita dapati pada umumnya dalam kumpulan sajak Taufiq Ismail "Tirani dan Benteng" yang mencerminkan keberanian para mahasiswa Indonesia menantang tirani, kepalsuan, penindasan untuk menegakkan kebenaran dan keadilan.

Berbagai nada yang diungkapkan penyair melalui puisinya seperti nada gemas karena usahanya memahami rahasia Tuhan berhasil seperti terungkap dalam puisi "O" oleh Sutardji Calzum Bachri. Nada main-main yang kita jumpai pada puisi mbeling oleh Remy Silado "Belajar Menghargai Hak Asasi Kawan". Nada revoioner penuh dengan semangat berkobar dan hasutan dapat kita jumpai dalam sajak penyair LEKRA yang sangat populer antara tahun 1962-1965 di Indonesia. Semangat berapi-api ini membangkitkan emosi meluap-luap tak terkendali seperti "Makan Roti Komune" oleh Sitor situmorang. Demikian nada pasrah karena tidak berdaya melawan kehendak nasib dapat kita hayati pada puisi Goenawan Muhammad "Asmaradana". Ia menarima nasib apapun yang terjadi pada dirinya.

Demikian nada hati penyair dalam puisinya. Nada hati penyair memberikan kesan yang mendalam kepada pembaca. Ungkapan total karena seluruh aspek psikologis penyair turut terlibat dan dikonsentrasikan untuk memperoleh daya gaib. Nada atau sikap penyair merupakan landasan tumpu atau setting.

\section{d. Amanat: tujuan dan maksud (intention)}

Orang hidup ada tujuan, orang bekrja ada maksud, orang belajar ada maksud dan ujuan. Tujuanlah yang orang melakukan sesuatu. Demikian penyair tujuan mendorng untuk menciptakan puisi. Amanat/tujuan adalah sesuatu yang hendak disampaikan penyair setelah memahami tema, rasa, dan nada. Jadi amanat dalam puisi maksud atau tujuan yang hendak disampaikan atau pesan yang ingin disampaikan penyair.

Sering kita baca dalam puisi berkaitan dengan amanat/tujuan yaitu jika penyair seorang guru maka karyanya memdidik pembacanya, jika penyair seorang ulama dia membawa penikmatnya ke jalan yang diridhoi oleh Tuhan, jika penyair seorang filsuf sajaknya bersifat filosofis. Waluyati ingin berfalsafah sehingga sajaknya bernilai filosofis.

\section{Nanti, nantikanlah!}

Rumput kering kemuning

Terhampar luas.

Gemetar tampak hawa panas atas padang sunyi.

Ah, Rumput, akarmu jangan turut mongering;

jangan mati kaku ditanah terbaring.

Nanti, nantikanlah

dengan sabar dan tabah

sampai hujan turun membabasahi

bumi.

Demikian amanat puisi merupakan maksud yang hendak disampaikan penyair. Tiap penyair bermaksud ingin membangkitkan martabat manusia dan kemanusiaan. Penghayatan terhadap amanat sebuah puisi tidak secara objektif, tetapi subjektif. Artinya penafsiran terhadap puisi tersebut berdasarkan interpretasi pembacanya. Oleh karena itu, sejarah sastra, penyair serta aliran yang dianut, filsafat, dan zamannya merupakan sumbangan terhadap penafsiran amanat 
sebuah puisi sehingga penafsiran mendekati kehendak penulisnya.

\section{e. Teknik Brainstorming (Teknik Ramu Pendapat)}

Teknik ini merupakan perpaduan antar teknik Tanya-jawab dengan teknik Diskusi. Teknik ini sangat tepat diterapkan dalam pembelajaran sastra. Siswa diajak untuk mendiskusikan karya sastra berupa cerpen, novel, dan puisi. Misalnya, membahas puisi dengan membicarakan unsur-unsur yang membangun sebuah puisi, baik struktur fisik maupun struktur batin.

Apresiasi sastra puisi dengan struktur batin yang disebut juga dengan hakikat puisi berupa tema, rasa, nada, dan amanat. Untuk menganalisis hal tersebut sangat tepat digunakan teknik brainstorming. Teknik ini diterapkan dengan cara secara bergiliran siswa diberi kesempatan mengemukakan pendapatnya terhadap pertanyaan yang diajukan guru. Jawaban siswa diseleksi, diklasifikasi, dan dianalisis bersama dengan mereka. Jika terdapat jawaban mereka yang bertentangan, jawaban itu kita lemparkan lagi ke kelas lain untuk didiskusikan. Setelah diskusi, guru menyimpulkan hasil diskusi secara adil tanpa pilih kasih atau memihak.

Solhan (2007) menyebutkan beberapa keunggulan teknik brainstorming sebagai berikut: (1) dapat membangkitkan pikiran yang kreatif; (2) dapat merangsang partisipasi siswa; (3) dapat memancing timbulnya pendapat-pendapat baru; (4) menghasilkan reaksi berantai; (5) dapat digunakan dalam kelompok kecil atau kelompok besar; (6) tidak memerlukn moderator yang hebat; dan (7) hanya sedikit peralatan yang diperlukan.

\section{METODE PENELITIAN}

Penelitian ini dilakukan pada salah satu SD di Kecamatan Tombolo Pao Kabupaten Gowa. Subjek penelitian adalah murid kelas VI dengan jumlah siswa 24 orang, dengan komposisi 14 siswa perempuan dan 10 siswa laki-laki. Penelitian ini pada tahun pelajaran 2013/2014 di SD Inpres Lappara Kec. Tombolo Pao Kabupaten Gowa.

Adapun indikator yang ingin diteliti untuk menjawab permasalahaan di atas adalah : (1) ingin mengetahui kemampuan siswa memahami atau mengapresiasi puisi berupa tema, rasa, nada, dan amanat; (2) aktivitas siswa mengikuti pembelajaran dengan keknik brainstorming.

Penelitian tindakan kelas ini, rencana pelaksanaannya dua siklus untuk mengapresiasi puisi dari segi struktur batin berupa tema, rasa, nada, dan amanat. Kedua siklus tersebut terbagi dalam 4 tahapan. Semua tahapan kegiatan yang dilakukan terhadap PTK ini adalah perencanaan (plan), pelaksanaan tidakan (act), pengamatan/obsevasi (observe), dan refleksi (reflect).

Adapun alur pikir dalam pelaksanaan setiap siklus pada penelitian tindakan kelas seperti pada bagan berikut. Alur pikir pelaksanaan penelitian tindakan kelas mengikuti model Kemmis and MC. Taggart (dalam Wiriaatmadja, 2005:66-67).

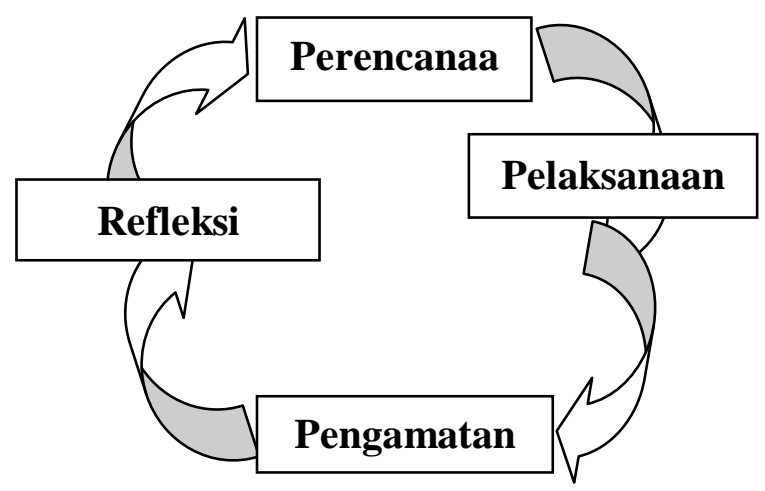

Data yang dikumpulksan melalui pemberian tes kemampuan memahami puisi setiap akhir permetuan. Adapun indikator dalam penelitian tindakan kelas ini adalah untuk mengetahui tingkat apresiasi puisi dalam hal tema, rasa, nada, dan amanat yang terdapat dalam puisi. Selain data hasil 
belajar yang diharapkan ada peningkatan aktivitas proses pembelajaran.

Data penelitian ini diperoleh dengan cara mengadakan tes meningkatkan kemampuan memahami isi puisi dalam hal tema, rasa, nada, dan amanat melalui teknik brainstorming. Tes yang disajikan berupa tes uraian 4 nomor dan pilihan ganda 20 nomor. Adapun tehnik pemberian nilai adalah untuk tes uraian bobotnya 20 dan pilihan ganda bobotnya juga 20 , nilai maksimal 40.

Kriteria pengujian didasarkan pada kemampuan siswa mengerjakan tes, yaitu apabila jumlah siswa subjek memperoleh nilai 65 di atas 85\%, maka tingkat kemampuan siswa dalam memahami isi puisi dikatan sudah berhasil. Sebaliknya, apabila tingkat kemapuan siswa subjek dalam memahami isi puisi di bawah $85 \%$ maka dianggap belum memadai atau belum berhasil.

\section{HASIL DAN PEMBEHASAN PENELITIAN}

\section{Deskripsi Hasil Siklus I}

Dari hasil tes, untuk mengetahui kemampuan siswa mengapresiasi puisi yang meliputi tema, rasa, nada, dan amanat melalui teknik brainstorming diperoleh gambaran nilai seperti tabel 1 berikut.

Tabel 1 Kemampuan siswa mengapresiasi puisi pada siklus I

\begin{tabular}{|c|c|c|c|c|c|}
\hline \multirow{2}{*}{ Aspek } & \multicolumn{4}{|c|}{ Kriteri penialain } & \multirow{2}{*}{ Ket. } \\
\cline { 2 - 5 } & Tema & Rasa & Nada & Amanat & \\
\hline Jumlah & 1560 & 1583 & 1599 & 1627 & \\
\hline Rata-rata & 65 & 65,96 & 66,63 & 67,79 & \\
\hline Terendah & 55 & 60 & 60 & 62 & \\
\hline Tertinggi & 75 & 75 & 75 & 80 & \\
\hline
\end{tabular}

Berdasarkan tabel di atas, dinyatakan bahwa dari 24 orang siswa mengapresiasi puisi sesuai dengan unsur-unsur yaitu (1) tema nilai rata-rata 65 nilai terendah 55 dan nilai tertinggi 75 ; (2) rasa nilai rata-rata 665,96 nilai terendah 60 nilai tertinggi 75 ; (3) nada nilai rata-rata 66,63 nilai terendah 60 tertinggi 75; dan (4) amanat nilai rata- rata 67,79 nilai terendah 62 nilai tertinggi 80.

Apabila kemampuan siswa mengapresiasi puisi dikaitkan dengan nilai standar kriteria ketuntasan minimal (KKM) 65, maka diperoleh gambaran seperti tebel 2 berikut. Tabel 2 Presentase kemampuan siswa mengapresiasi puisi sesuai KKM Siklus I

\begin{tabular}{|c|c|c|c|c|l|}
\hline \multirow{2}{*}{ Nilai KKM 65 } & \multicolumn{4}{|c|}{ Kriteri dalam jumlah subjek } & \multirow{2}{*}{ Rata-rata \% } \\
\cline { 2 - 5 } & Tema & Rasa & Nada & Amanat & \\
\hline Kecil dari 65 & 13 & 12 & 12 & 13 & $52,09 \%$ \\
Besar dari 65 & 11 & 12 & 12 & 11 & $47,91 \%$ \\
\hline Jumlah & 24 & 24 & 24 & 24 & $100 \%$ \\
\hline
\end{tabular}

Sesuai dengan tabel di atas, maka siswa yang memperoleh nilai lebih kecil dari 65 berdasarkan kriteria yaitu tema (13 orang ), rasa (12 orang), nada (12 orang), amanat (13 orang) dan rata-rata persentase $52,09 \%$. Perolehan nilai lebih besar dari 65 yaitu tema 114 orang), rasa (12 orang), nada(12 orang) dan amanat (11 orang) dan rata-ata persentase $47,91 \%$.

\section{Temuan dan Refleksi Siklus I}

Berdasarkan hasil tentang kemampuan siswa pada siklus I, mengapresiasi puisi dengan fokus (tema, rasa, nada, amanat) 
melalui teknik brainstorming, diperoleh gambaran bahwa dari 6 orang siswa setelah mengikuti proses pembelajaran dan diberikan tes, belum berhasil secara klasikal.

Sesuai dengan data, dinayatakan bahwa pelaksanaan pembelajaran pada siklus I belum berhasil maksimal karena nilai 65 ke atas belum mencapai $85 \%$ setiap kriteria. Oleh karena itu, untuk menuntaskan pelaksanaan pembelajaran perlu tindakan siklus II. Pelaksanaan siklus II diharapakan meningkatkan hasil yang lebih baik sebagai refleksi siklus I mengapresiasi puisi berupa tema, rasa, nada, dan amanat melalui teknik brainstorming.

Berdasarkan hasil pengamatan pembelajaran pada siklus I ada hal yang perlu diperbaiki yaitu perhatian siswa terhadap pelajaran dan penguasaan terhadap sastra belum memadai. Hal ini mengakibatkan perolehan nilai siswa belum maksimal sehingga perlu tindakan siklus II.

\section{Deskripsi Hasil Siklus II}

Berdasarkan hasil yang diperoleh pada pelaksanaan siklus II, untuk mengetahui kemampuan siswa mengapresiasi puisi yang meliputi tema, rasa, nada, dan amanat melalui teknik brainstorming dengan lebih mengaktifkan siswa belajar dan membekali konsep pengetahuan apresiasi puisi. Setelah dites diperoleh gambaran nilai seperti tabel 3 berikut.

Tabel 3 Kemampuan siswa mengapresiasi puisi pada siklus I

\begin{tabular}{|c|c|c|c|c|c|}
\hline \multirow{2}{*}{ Aspek } & \multicolumn{4}{|c|}{ Kriteri penialain } & \multirow{2}{*}{ Ket. } \\
\cline { 2 - 5 } & Tema & Rasa & Nada & Amanat & \\
\hline Jumlah & 1652 & 1652 & 1775 & 1741 & \\
\hline Rata-rata & 68,83 & 68,63 & 73,96 & 72,54 & \\
\hline Terendah & 60 & 60 & 64 & 65 & \\
\hline Tertinggi & 75 & 80 & 85 & 85 & \\
\hline
\end{tabular}

Berdasarkan tabel di atas, dinyatakan bahwa dari 6 orang siswa mengapresiasi puisi sesuai dengan unsur-unsur yaitu (1) tema nilai rata-rata 68,83 nilai terendah 60 dan nilai tertinggi 75 ; (2) rasa nilai rata-rata 68,63 nilai terendah 60 nilai tertinggi 80; (3) nada nilai rata-rata 73,96 nilai terendah 64 tertinggi 85; dan (4) amanat nilai rata-rata 72,54 nilai terendah 65 nilai tertinggi 85 .

Apabila

kemampuan siswa mengapresiasi puisi dikaitkan dengan nilai standar kriteria ketuntasan minimal (KKM) 65 , maka hasil yang diperoleh gambaran seperti pada tebel 4 berikut.

Tabel 4 Presentase kemampuan siswa mengapresiasi puisi sesuai KKM Siklus II

\begin{tabular}{|c|c|c|c|c|l|}
\hline \multirow{2}{*}{ Nilai KKM 65 } & \multicolumn{4}{|c|}{ Kriteri dalam jumlah subjek } & \multirow{2}{*}{ Rata-rata \% } \\
\cline { 2 - 5 } & Tema & Rasa & Nada & Amanat & \\
\hline Kecil dari 65 & 5 & 4 & 3 & 0 & $12,50 \%$ \\
Besar dari 65 & 19 & 20 & 21 & 24 & $87,50 \%$ \\
\hline Jumlah & 24 & 24 & 24 & 24 & $100 \%$ \\
\hline
\end{tabular}

Sesuai dengan tabel di atas, maka siswa yang memperoleh nilai lebih kecil dari 65 berdasarkan kriteria yaitu tema, rasa, nada, dan amanat dan rata-rata persentase $12,50 \%$. Perolehan nilai lebih besar dari 65 yaitu tema, rasa, nada, dan amanat dan rata-rata persentase $87,50 \%$.

\section{Temuan dan Refleksi Siklus II}

Berdasarkan hasil tes, kemampuan 
siswa pada siklus II, mengapresiasi puisi dengan fokus (tema, rasa, nada, amanat) melalui teknik brainstorming siswa diperoleh gambaran bahwa dari 24 orang siswa setelah mengikuti proses pembelajaran dan diberikan tes, menunjukkan suatu hasil yang memuaskan.

Sesuai dengan data, dinayatakan bahwa pelaksanaan pembelajaran pada siklus II ini berhasil maksimal karena nilai $65 \mathrm{ke}$ atas sudah mencapai $87,50 \%$. Hal ini menunjukkan bahwa proses pelaksanaan pembelajaran pada siklus II meningkatkan hasil mengapresiasi puisi berupa tema, rasa, nada, dan amanat melalui teknik brainstorming.

\section{Pembahasan Hasil Penelitian}

Berdasarkan hasil dan temuan pada penelitian tindakan kelas ini menunjukkan suatu peningkatan. Terdapat aktivitas siswa terhadap proses pembelajaran apresiasi puisi. Demikian peningkatan hasil setiap pelaksanaan tindakan siklus. Meningkatnya pemahaman konsep apresiasi puisi dengan fokus tema, rasa, nada, dan amanat pada siswa kelas VI SD Inpres Lappara Kecamatan Tombolo Pao.

Hasil yang diperoleh dalam mengapresiasi puisi sesuai dengan kriteria pada siklus I ke siklus II melalui teknik brainstorming yaitu (1) tema dengan nilai rata-rata 65 meningkat menjadi 68,83; (2) rasa dengan nilai rata-rata 65,96 meningkat menjadi 68,83 ; (3) nada dengan nilai rata-rata 66,63 meningkat menjadi 73,96; dan (4) amanat dengan nilai rata-rata 67,79 meningkat menjadi 72,54 dan nilia terendah 55 meningkat menjadi 65 nilai tertinggi 80 meningkat menjadi 85 .

Sedangkan persentase kemampuan siswa mengapresiasi puisi dikaitkan dengan nilai standar kriteria ketuntasan minimal (KKM) 65 pada siklus I ke siklus II mengalani perubahan sesuai kriteria yaitu, (1) tema, dari 13 orang siswa belum tuntas berubah menjadi 5 orang yang belum tuntas, rasa dari berubah menjadi 12 orang siswa belum tuntas berubah menjadi 4 orang yang belum tuntas, nada dari 12 orang siswa belum tuntas berubah menjadi 3 orang yang belum tuntas, dan amanat dari 13 orang siswa berubah menjadi tuntas semua; (2) perolehan nilai lebih besar dari 65 yaitu tema dari 11 orang siswa menjadi 19 orang siswa, rasa dari 12 orang siswa menjadi 20 orang siswa, nada dari 12 orang siswa menjadi 21 orang siswa, dan amanat dari 11 orang siswa menjadi 24 orang siswa.

Sesuai dengan hasil dan pengamatan pada siklus II, terjadi perubahan proses, aktivitas, dan peningkatan hasil belajar. Siswa yang memperoleh nilai lebih kecil dari 65 mengalami perubahan rata-rata persentase setiap siklus yaitu $52,09 \%$ pada siklus I menurun menjadi $12,50 \%$ pada siklus II dan perolehan nilai lebih besar dari 65 juga meningkat dari 47,91\% pada siklus I meningkat menjadi $87,50 \%$ pada siklus II dengan penerapan teknik brainstorming terhadap pembelajaran mengapresiasi puisi siswa kelas VI SD Inpres Lappara.

\section{E. KESIMPULAN DAN SARAN}

\section{Kesimpuan}

Berdasarkan hasil analisis data dan pembahasan yang diuraikan di atas, maka dapat disimpulkan sebagai berikut: (1) penerapan teknik brainstorming dapat meningkatkan hasil belajar bahasa Indonesia khususnya mengapresiasi puisi tentang tema, rasa, dana, dan amanat; (2) aktivitas mengikuti proses pembelajaran terhadap apresiasi puisi terjadi peningkatan yang signifikan; (3) perolehan nilai rata-rata pada siklus I setiap kriteria meningkat pada siklus II; (4) rata-rata persentase perolehan nilai lebih kecil dari 65 pada siklus I yaitu $52,09 \%$ menurun pada siklus II menjadi $12,50 \%$ dan rata-rata persentase nilai lebih 
besar dari 65 pada siklus I $47,91 \%$ meningkat menjadi $87,50 \%$ pada siklus II.

\section{Saran}

Sesuai dengan hasil pembahasan dan kesimpulan, maka penulis menyarankan (1) seyogiyanya guru kelas VI SD Inpres Lappara Kecamatan Tombolo Pao Kabupaten Gowa dalam mengapresiasi puisi dapat menerapkan teknik brainstorming; (2) dengan menerapkan teknik brainstorming dapat meningkatkan proses dan hasil belajar bahasa Indonesia siswa khususnya pembelajaran apresiasi puisi tentang tema, rasa, nada, dan amanat; (3) dengan menerapkan teknik brainstorming dapat mengubah aktivitas siswa belajar dari kurang aktif menjadi aktif.

\section{F. DAFTAR PUSTAKA}

Ali, Lukman. 1999. Kamus Besar Bahasa Indonesia. Jakarta: Depdikbud Balai Pustaka

Effendi, S. 1982. Bimbingan Apresiasi Puisi. Jakarta: Tangga Mustika Alam.

Hayati, A.M. 1990. Apresiasi Sastra. Malang: YA Tiga Malang.

Solhan T.W., dkk. 2007. Pendidikan Bahasa Indonesia SD. Jakarta: Universitas Terbuka.

Tarigan, Henry Guntur. 1986. Prinsipprinsip Dasar Sastra. Bandung: Angkasa.

Waluyo, Herman J. 1987. Teori dan Apresiasi Puisi. Jakarta: Erlangga.

Wiraatmaja, Rochiati. 2005. Metode Penelitian Tindakan Kelas. Bandung: Remaja Rosdakarya 